Ethiopian Journal of Environmental Studies and Management EJESM Vol. 5 no.4 (Suppl.1) 2012

\title{
GROUNDWATER HYDROCHEMISTRY EVALUATION IN RURAL BOTSWANA: A CONTRIBUTION TO INTEGRATED WATER RESOURCES MANAGEMENT \\ BATISANI, N. \\ http://dx.doi.org/10.4314/ejesm.v5i4.S12
}

\begin{abstract}
Received 19th July 2012; accepted 9th October 2012

Groundwater is one of the major sources of exploitation in arid and semi -arid regions. To protect this scarce resource information on its quality status over time is important. This paper examines the quality of groundwater from domestic water supply boreholes across rural Botswana. lonic concentrations of $\mathrm{K}^{+}, \mathrm{Na}^{+}, \mathrm{Ca}^{2+}, \mathrm{Mg}^{2+}, \mathrm{F}, \mathrm{Cl}^{-}, \mathrm{SO}_{4}{ }^{2-}, \mathrm{HCO}_{3}{ }^{-}, \mathrm{Fe}^{3+}, \mathrm{Mn}^{-}$, and $\mathrm{N}$. Parameters such as $\mathrm{pH}$, total dissolved solids (TDS), and electrical conductance (EC) were correlated and their levels compared to international standards. Levels of various physico-chemical parameters were also analyzed for temporal trends for in the various districts across the country and those with significant trends were then contoured to determine areas at risk of groundwater contamination. Groundwater in rural Botswana is generally suitable for human consumption despite high levels of cations. Nevertheless, levels of $\mathrm{Na}^{+}, \mathrm{Ca}^{2+}, E C$ and TDS are showing increasing trends in some parts of the country highlighting the need for periodic monitoring of groundwater quality to isolate and possibly advise on discontinuation of polluted boreholes.
\end{abstract}

\section{Key words: Groundwater, Rural, Physico-chemical, Water Resources, Botswana}

\section{Introduction}

Extreme climate conditions in the form of higher maximum temperatures and frequent droughts are expected in the twenty-first century due to climate change. In particular, Africa and Asia are expected to become more vulnerable to droughts (Sukhija, 2008). This situation is expected to affect arid regions most as humanity's sustenance hinges on groundwater in these places (Sukhija, 2008). Khodapanah et al. (2009) noted that groundwater is the only reliable water resource for human consumption in semi-arid regions. While (JMP, 2008, MacDonald et al., 2009) observed that one of the key uncertainties surrounding the impacts of a changing climate in Africa is its effect on the sustainability of rural water supplies. Furthermore, the rapid depletion of groundwater supplies as a consequence of continued population growth and pollution threatens the quality of many aquifers in these regions (Khodapanah et al., 2009).Once the groundwater is contaminated, its quality cannot be restored by stopping the pollutants from the sources. It therefore becomes imperative to regularly monitor the quality of groundwater and to device ways and means to protect it (Lateef, 2011).

Department of Agricultural Engineering and Land Planning, University of Botswana, Private Bag 0027 Gaborone,

Botswana

nnyaladzi.batisani@gmail.com
In many areas, particularly arid and semiarid zones such as Botswana, groundwater quality limits the supply of potable fresh water. To utilize and protect valuable water resources effectively and predict the change in groundwater environments, it is necessary to understand the hydrochemical characteristics of the groundwater and its evolution under natural water circulation processes (Lawrence et al., 2000; Edmunds et al., 2002, 2006; Guendouz et al., 2003; Wen et al., 2005; Ma et al., 2005; Ma and Edmunds 2006; Jianhua et al., 2009).

Thus, knowing the quality of groundwater is a crucial component of integrated water resources management. As such improved knowledge can contribute to effective management and utilization of this vital resource. In this regard, monitoring the quality of groundwater is as important as assessing its quantity (Khodapanah et al., 2009). Botswana is part of the drought prone region of Southern Africa, therefore, conservation and careful management of water resources is a matter of necessity and great importance. Hence the focus on water resources management in the country and in particular, an integrated approach that links both ground and surface sources has become critical over the past decade (Ganesan, 2001). 
Consequently, the goal of this paper is to add to overall knowledge on groundwater status and subsequently water resources management in Botswana. It reaches this goal through three analyses. The first analysis evaluates various water quality parameters through basic statistics in an attempt to compare their levels with acceptable international standards. The second analysis determines trend in levels of various parameters over time to identifying areas at risk of water pollution. Thirdly, significant trends of physico-chemicalparameter levels were displayed spatially explicitly.

\section{Materials and Methods Study Area}

Botswana is a land-locked country straddling the tropic of Capricorn in the center of the southern African plateau. The mean altitude above sea level is approximately 1000 $\mathrm{m}$, with total land area of $582,000 \mathrm{~km}^{2}$ and population of 2 million. The country shares borders with Zimbabwe, South Africa, Namibia, and Zambia (Figure 1). Much of the country is flat, with gentle undulating, occasionally rocky, outcrops. About two thirds of the land comprises the kgalagadi desert, which supports scrubs and grasses, despite almost lacks surface water sources.

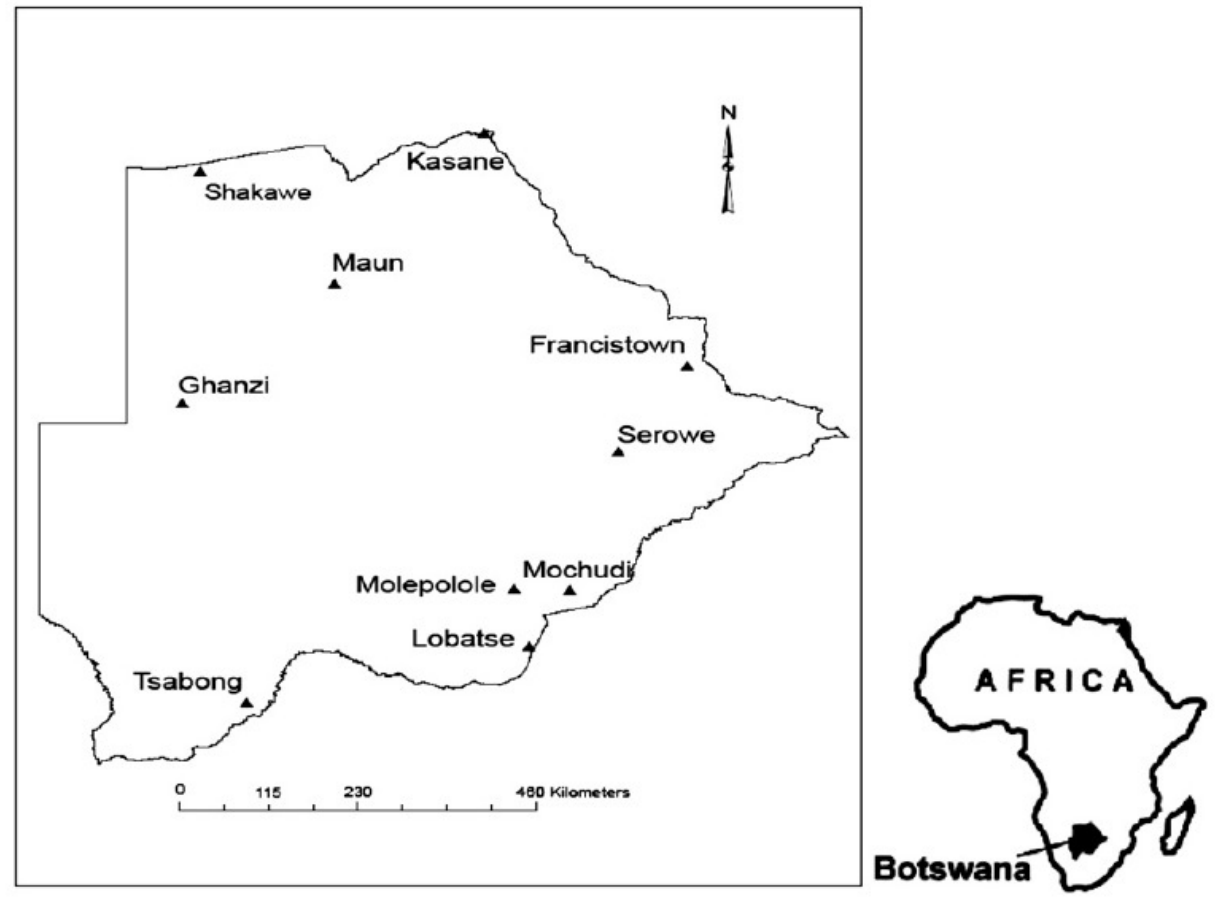

Figure 1 Map of Study Area

Botswana is situated close to the subtropical high pressure belt of the southern hemisphere. As a result, the country is largely arid or semiarid. Mean annual rainfall ranges from $650 \mathrm{~mm}$ in the extreme northeast to less than $250 \mathrm{~mm}$ in the extreme southwest. Almost all the rainfall occurs during the summer months, from October to April, while May to September is normally dry. Most of the rainfall occurs in localized showers and thunderstorms, and its incidence is highly variable both in time and in space. Average daily maximum and minimum temperatures range from $22^{\circ} \mathrm{C}$ in July to $33^{\circ} \mathrm{C}$ in January (max.) and $5^{\circ} \mathrm{C}$ in July to $19^{\circ} \mathrm{C}$ in January (min.). Evaporation rates are high, ranging from 1.8 to $2.2 \mathrm{~m}$ annually for surface water. Clear skies and low relative humidity lead to maximum insolation during the day and rapid energy loss at night, resulting in relatively hot days and cool nights and a large diurnal of temperature range. Drought is a recurring event in the country resulting in poor crop production and reduction in livestock population (Khupe, 1996). 


\section{Groundwater Resources in Botswana}

Groundwater is the main source of portable water supply in Botswana. Much of the country (about 66 percent) depends entirely on groundwater (Table 1). Although groundwater recharge is very limited, thus making the resource finite and non-renewable, it is an indispensable water resource in the country. With the envisaged increase in water demand in the country, (Figure 2), its importance is set to increase. Besides pollution, over abstraction is likely to be a threat in to groundwater sustainability in the future (Table 2).

Table 1. Availability of groundwater in Botswana (2008)

\begin{tabular}{lccc}
\hline Wellfield & $\begin{array}{c}\text { Developed available } \\
\text { resource }\left(\mathbf{m}^{3} / \mathbf{d}\right)\end{array}$ & $\begin{array}{c}\text { Cumulative } \\
\text { Resources developed } \\
\left(\mathbf{m}^{3} / \mathbf{d}\right)\end{array}$ & $\begin{array}{c}\text { Sustainable Resource } \\
\left(\mathbf{M m}^{3} / \mathbf{y r}\right)\end{array}$ \\
\hline Dukwi & 5700 & 5700 & 0.039 \\
Palla Road & 7500 & 13200 & 1.46 \\
Ghanzi & 1850 & 15050 & 0.68 \\
Kanye & 3950 & 19000 & 1.44 \\
Letlhakane & 1500 & 20500 & 0.06 \\
Gaotlhobogwe & 7500 & 28000 & 5.84 \\
Palapye & 4000 & 32000 & 1.64 \\
Ramotswa & 5000 & 37000 & 1.83 \\
Serowe & 6200 & 43200 & 1.28 \\
Tsabong & 2000 & 45200 & 0.73 \\
Kang-Phuduhudu & 7860 & 53060 & 3.27 \\
Boteti & 8950 & 62010 & 1.96 \\
Maitengwe & 9400 & 71410 & 3.43 \\
Matsheng & 9600 & 81010 & 3.52 \\
Pitsanyane & 1000 & 82010 & 0.37 \\
Maun & 8000 & 90010 & 10.07 \\
Masama* & 20480 & 110490 & - \\
Botlhapatlou* & 14000 & 124490 & - \\
Bobonong* & 3800 & 128290 & - \\
Mabule Dolomite & 3000 & 131290 & - \\
Cluster* & & & \\
\hline & & & \\
\hline
\end{tabular}

(Department of Water Affairs, 2008)

NB: $\mathrm{m}^{3} / \mathrm{d}$ refers to cubic metres per day, $\mathrm{Mm}^{3} / \mathrm{yr}$ refers to million cubic metres per year *expected yield per day

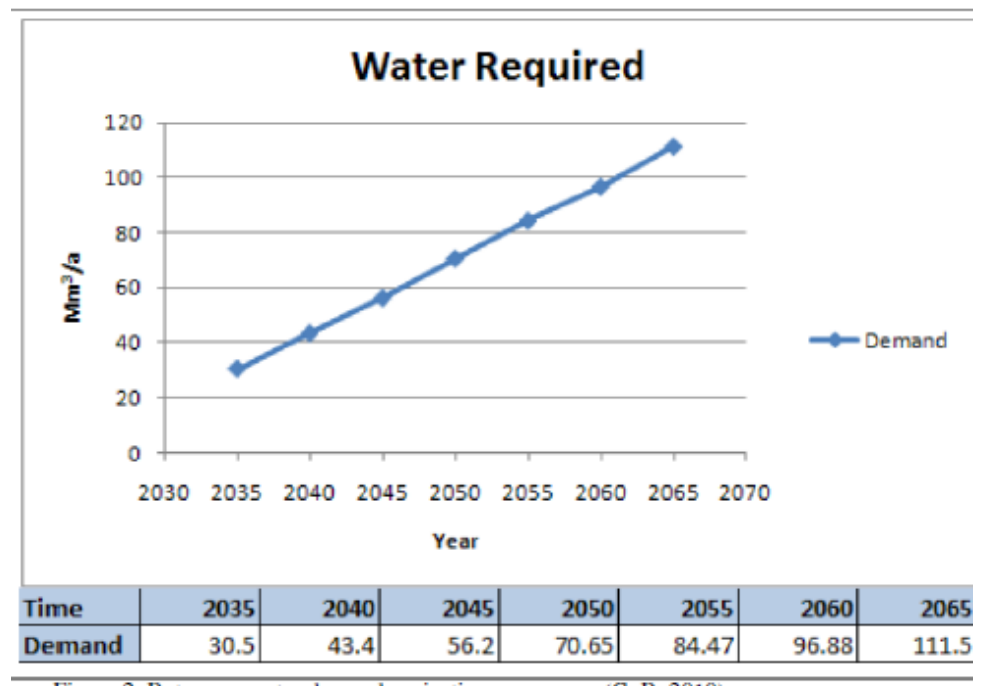

Figure 2. Botswana water demand projection per annum (GoB, 2010). 
Table 2. Sustainable Groundwater Resources in Botswana (2008)

\begin{tabular}{|lcccc|}
\hline Wellfield & $\begin{array}{c}\text { Available } \\
\text { Developed } \\
\text { resource }\end{array}$ & $\begin{array}{c}\text { Sustainable } \\
\text { Resource } \\
\left(\mathbf{m}^{3} / \mathbf{d}\right.\end{array}$ & $\begin{array}{c}\text { Current } \\
\text { Abstraction } \\
\left(\mathbf{m}^{\mathbf{3}} / \mathbf{d}\right)\end{array}$ & $\begin{array}{c}\text { Annual } \\
\text { Abstraction } \\
\left(\mathbf{M m}^{\mathbf{3}} / \mathbf{y}\right)\end{array}$ \\
\hline Dukwi & 5700 & 600 & 6600 & 2.44 \\
Mahalapye & 7500 & 4000 & 4000 & 1.48 \\
Ghanzi & 1850 & 1850 & 1850 & 0.69 \\
Kanye & 3950 & 3950 & 6900 & 2.56 \\
Letlhakane & 1500 & 950 & 1500 & 0.56 \\
Palapye & 4000 & 2700 & 3200 & 1.19 \\
Ramotswa & 5000 & 5000 & 4000 & 1.48 \\
Serowe & 6200 & 3500 & 4500 & 1.67 \\
Tsabong & 2000 & 300 & 1600 & 0.59 \\
\hline
\end{tabular}

(Department of Water Affairs, 2008)

Data

Ionic concentrations of $\mathrm{K}^{+}, \mathrm{Na}^{+}, \mathrm{Ca}^{2+}$, $\mathrm{Mg}^{2+}, \mathrm{F}^{-}, \mathrm{Cl}^{-}, \mathrm{SO}^{2-}, \mathrm{HCO}^{-}, \mathrm{Fe}^{3+}, \mathrm{Mn}^{-}$, and $\mathrm{NO}_{3}^{-}$; along with $\mathrm{pH}$, total dissolved solids (TDS), and electrical conductance (EC) of groundwater (boreholes) for domestic use across the country for the period of 1985-2006 at district level were obtained from the Department of Water Affairs, Botswana Government.

\section{Analysis}

Basic descriptive statistics such as correlation matrix and range were calculated to evaluate water quality standard. While level trends of various parameters over time were determined through Mann-Kendall test (MK) (Mann, 1945, Kendall, 1975; Turkes et al., 2002). In MK, the standardized statistical test ( $\mathrm{Z}$ ) is used, with positive $\mathrm{Z}$ values indicating increasing trends and negative $Z$ values indicates decreasing trends. When testing either increasing or decreasing monotonic trends at a $p$ significance level, the null hypothesis is rejected for absolute values of $\mathrm{Z}$ greater than $Z_{1-p / 2}$, obtained from the standard normal cumulative distribution tables. In this paper, standard significance levels of $p=0.05$ and 0.10 were applied. Parameters showing significant trends were then contoured using the spline interpolation technique in ArcGIS 9.2 to determine areas at risk of ground water contamination.

\section{Results and Discussion}

Correlation matrix between the different chemical parameters was computed in order to deduce geochemical processes determining the quality of groundwater (Table 1). Statistics of groundwater show poor correlation ions. Nevertheless a few such as EC with TDS, EC with $\mathrm{Ca}^{+2}$ and $\mathrm{Mg}^{+2}, \mathrm{Mg}^{+2}$ with $\mathrm{Cl}^{-}, \mathrm{Ca}^{+2}$ with $\mathrm{Mg}^{+2}, \mathrm{Ca}^{+2}$ with $\mathrm{So}_{4}^{2-}$, and $\mathrm{Na}^{-}$with $\mathrm{HCO}^{-}$ show moderate to high correlation. High correlation and also level indicate chemical weathering and leaching of secondary salts contribution followed by multiple source inputs like industrial and agricultural effluents, which exhibit poor correlation in groundwater (Udayalaxmi et al., 2010). Other anthropogenic sources such as sewage effluent (McCarthy et al., 1994) also play a major role in controlling shallow groundwater chemistry.

A high positive correlation is observed between TDS and EC because conductivity increases as the concentration of all dissolved constituents/ions increases. Likewise, a strong correlation is also observed between $\mathrm{Mg}^{2+}$ and $\mathrm{Ca}^{+2}$ indicating most of the ions are involved in various physiochemical reactions, such as oxidation-reduction and ion exchange in the groundwater aquifer system (Udayalaxmi et al., 2010). A marginal negative correlation is seen between the $\mathrm{pH}$ and all other parameters, except potassium (Table 3). 
Table 3. Correlation matrix for groundwater quality

\begin{tabular}{|c|c|c|c|c|c|c|c|c|c|c|c|c|c|c|}
\hline & $\mathrm{Na}^{+}$ & $\mathrm{K}^{+}$ & $\mathrm{Ca}^{2+}$ & $\mathrm{Mg}^{2+}$ & $\mathrm{Cl}^{-}$ & $\mathrm{SO}^{2-}$ & $\mathrm{HCO}^{-}$ & $\mathrm{NO}_{3}$ & $\mathrm{pH}$ & TDS & $\mathrm{Fe}^{3+}$ & $F$ & $\mathrm{Mn}$ & EC \\
\hline $\mathrm{Na}^{+}$ & 1 & & & & & & & & & & & & & \\
\hline $\mathrm{K}^{+}$ & 0.19 & 1 & & & & & & & & & & & & \\
\hline $\mathrm{Ca}^{2+}$ & $0.73^{*}$ & & 1 & & & & & & & & & & & \\
\hline $\mathrm{Mg}^{2+}$ & -0.05 & & 0.84 & 1 & & & & & & & & & & \\
\hline $\mathrm{Cl}^{-}$ & 0.13 & 0.17 & 0.45 & 0.83 & 1 & & & & & & & & & \\
\hline $\mathrm{SO}_{4}^{2-}$ & 0.83 & & 0.79 & 0.13 & 0.53 & 1 & & & & & & & & \\
\hline $\mathrm{HCO}^{-}$ & 0.84 & & 0.01 & 0.13 & 0.01 & 0.21 & 1 & & & & & & & \\
\hline$N$ & & & & & & & & 1 & & & & & & \\
\hline $\mathrm{pH}$ & -0.19 & 0.43 & -0.24 & -0.27 & -0.04 & -0.22 & -0.53 & & 1 & & & & & \\
\hline TDS & 0.55 & 0.20 & 0.43 & 0.51 & 0.93 & 0.61 & 0.14 & -0.21 & -0.19 & 1 & & & & \\
\hline $\mathrm{Fe}^{3+}$ & & & 0.36 & -0.40 & & & & & & & 1 & & & \\
\hline $\mathrm{F}$ & & & & & & & & & & -0.18 & & 1 & & \\
\hline $\mathrm{Mn}^{-}$ & & & 0.12 & -0.02 & & & & & 0.54 & & & & 1 & \\
\hline EC & 0.68 & 0.08 & 0.86 & 0.77 & 0.64 & 0.49 & 0.13 & & -0.37 & 0.87 & & & & 1 \\
\hline
\end{tabular}

\section{Groundwater Chemistry}

Among major cations, $\mathrm{Na}^{+}$was generally dominant with concentration ranging from 38.4 to $450 \mathrm{mgl}^{-1}$. Calcium ion was second highest with maximum concentration of 98 $\mathrm{mgl}^{-1}$. Potassium and magnesium ions were of secondary importance, with maximums of 29 and $58 \mathrm{mgl}^{-1}$ respectively. While maximum concentrations of chloride, sulfate and bicarbonate ions were 532, 220, and $287 \mathrm{mgl}^{-1}$ respectively. The electrical conductivity (EC) varies from 300 to $18200 \mu$ mhos $\mathrm{cm}^{-1}$ indicating that there are fresh water $(<500$ $\mu$ mhos $\left.\mathrm{cm}^{-1}\right)$, marginal water $(500-1500$ $\mu$ mhos $\mathrm{cm}^{-1}$ ) and brackish water types $\left(>1500 \mu \mathrm{mhos} \mathrm{cm}^{-1}\right)$ in domestic groundwater boreholes in the country. Total dissolved solids ranges from 245 to $583 \mathrm{mgl}^{-1}$. The $\mathrm{pH}$ value is high (8.5 to 10.3) indicating the alkaline nature of rural groundwater in the country (Table 4).

Table 4. Physico-chemical characteristics of groundwater in rural Botswana

\begin{tabular}{lcc}
\hline Parameter & Range $\left(\mathrm{mgl}^{-1}\right)$ & WHO limit (2004) \\
\hline $\mathrm{Na}^{+}$ & $38.4-450$ & 200 \\
$\mathrm{~K}^{+}$ & $2-29$ & 30 \\
$\mathrm{Ca}^{2+}$ & $26-98$ & 200 \\
$\mathrm{Mg}^{2+}$ & $14-58$ & 150 \\
$\mathrm{Cl}^{-}$ & $110-532$ & 250 \\
$\mathrm{SO}^{2-}$ & $34-220$ & 400 \\
$\mathrm{HCO}^{-}$ & $72-287$ & - \\
$\mathrm{NO}_{3}^{-}$ & $0.32-9.2$ & 10 \\
$\mathrm{pH}$ & $8.5-10.3$ & $6.5-8.5$ \\
$\mathrm{TDS}$ & $245-583$ & 1000 \\
$\mathrm{~F}$ & $0.10-1.20$ & 1.50 \\
$\mathrm{EC}$ & $0.30-18.20(\mathrm{mS} / \mathrm{m})$ & - \\
\hline
\end{tabular}


Spatio-Temporal Physico-Chemical Trends

Of the various chemical parameters evaluated, only $\mathrm{Ca}^{2+}, \mathrm{EC}, \mathrm{pH}$, and TDS showed significant temporal trends at different boreholes across the country, which were then interpolated to get country coverage. Calcium levels depict increasing trend in the extreme north of the country while decreasing in the southern part. Electrical conductivity shows increasing trend in the dry south west and also in the north east but decreasing in the north and southern parts. Trends in $\mathrm{pH}$ across the country display increase in the southwest, and decrease in the north and northeast.TDS show a decreasing trend for most parts of the country except the northeast (Table 5, Figure $3)$.

Table 5. Groundwaterphysico-chemical temporal trends across the country

\begin{tabular}{|l|l|l|l|l|l|l|l|l|}
\hline District & $\begin{array}{l}\text { EC } \\
\text { trend }\end{array}$ & $\mathbf{p}$ value & $\mathbf{p H}$ & $\mathbf{p}$ value & TDS & p value & Ca & p value \\
\hline Central (central) & 1.69 & $0.009^{* * *}$ & -1.41 & 0.16 & 0.48 & 0.63 & -0.59 & 0.55 \\
\hline Chobe (north) & -1.38 & $0.01^{* * *}$ & 0.90 & 0.37 & -1.72 & $0.09^{* * * *}$ & 0.81 & $0.02^{* *}$ \\
\hline Kgatleng (southern) & -3.67 & $0.000^{*}$ & 2.20 & $0.003^{* *}$ & -3.19 & $0.000^{*}$ & -1.04 & $0.03^{* *}$ \\
\hline Kgalagadi (south western) & 0.68 & $0.005^{* * *}$ & -1.58 & 0.11 & 0.73 & 0.46 & -0.28 & $0.04^{*}$ \\
\hline South-East & -0.82 & $0.004^{* *}$ & -2.85 & $0.000^{*}$ & -0.10 & 0.34 & -0.03 & $0.006^{* * *}$ \\
\hline
\end{tabular}

*Significant at $\mathrm{p}<0.001,{ }^{*} *$ significant at $\mathrm{p}<0.005, * * *$ significant at $\mathrm{p}<0.1$
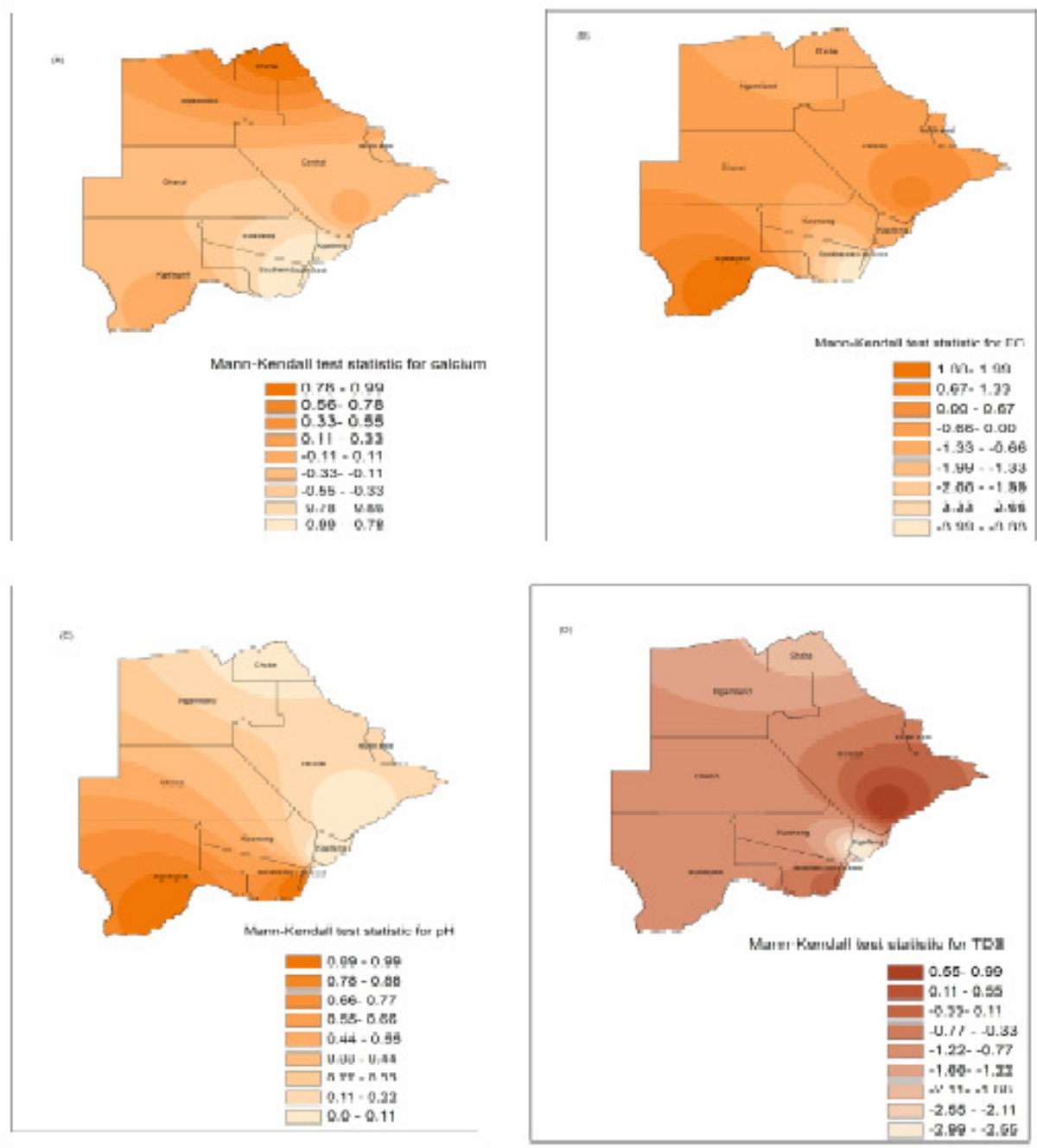

Figure 3. Trends in physico-chemical levels 


\section{Water Quality Assessment}

The goal of hydrogeochemical assessment is to determine groundwater suitability to different uses based on different chemical indices. An assessment of rural borehole water suitability for domestic consumption was evaluated by comparing the aggregated hydrochemical parameters of the water with prescribed specification of World Health Organization (WHO, 2004) (Table 4). Although the desirable $\mathrm{pH}$ range for drinking water is 6.5 to 9.2 , the range for rural groundwater in Botswana is 8.5 to 10.3 , indicating the alkaline nature of the water and values outside WHO standards. Furthermore, the upper range of EC is also more than the maximum permissible limit of $1500 \mu \mathrm{mhos} \mathrm{cm}$ ${ }^{-1}$.In the same vain, the upper range of sodium is also outside the prescribed limit of $200 \mathrm{mgl}^{-}$ 1

\section{Conclusion}

This paper evaluated the quality status of groundwater in Botswana; a vital component of integrated water resources management. In general, groundwater in the country is suitable for human consumption except for some high levels of cations. The Physico-chemical levels are constant across the country except for $\mathrm{Ca}$, $\mathrm{EC}, \mathrm{pH}$, and TDS, which depict either increasing or decreasing trends in different parts of the country. Therefore, periodic monitoring of groundwater quality to isolate and possibly advise on discontinuation of boreholes with high levels of physicochemicals need to be carried out. Such groundwater quality monitoring could, provide invaluable information for water management strategies.

\section{References}

Adriogué, J. and Wesson, D. (1994). Blackwell's basics of medicine: Potassium.

Blackwell Scientific Publications, Boston, MA Botswana Water Statistics. Central Statistics Office, Gaborone, Botswana

Buckley, N., Dawson, A. and Reith, D. (1995). Controlled release drugs in overdose: clinical considerations. Drug Saf. 12, 73-84.

Department of Water Affairs (2010). Feasibility Design Study on the Utilization of the Water Resources of the Chobe/Zambezi River. WRC. Republic of Botswana Ministry of Minerals, Energy and Water Resources
Ganesan, C. (2001). Water resources development and management $A$ challenging task for Botswana Water International. 26: 8085

Gosselin, R., Smith, R. and Hodge, H. (1984). Clinical toxicology of commercial products.5th edition.Williams \& Wilkins, Baltimore, MD.

JMP (Joint Monitoring Programme) (2008). Global water supply and sanitation report. Joint Monitoring Programme WHO/UNICEF. World Health Organization, Geneva, Switzerland

Kendall, M. (1975). Rank correlation methods. Charles Griffin, London.

Khodapanah, L., Sulaiman, W. and Khodapanah, N. (2009). Groundwater quality assessment for different purposes in Eshtehard District, Tehran, Iran. European Journal of Scientific Research, 36, 543-553

Khupe, J. (1996). Water supply, sewerage and waste management for Gaborone, Botswana. Ambio., 25, 134-137

Lateef, K. (2011). Evaluation of groundwater quality for drinking purpose for Tikrit and Samarra cities using Water quality index. European Journal of Scientific Research, 58, 472-481

Lewis, J. (1997). Hawley's condensed chemical dictionary. 13th edition. Van NostrandReinhold, New York, NY.

MacDonald, A., Calow, R., MacDonald, D., Darling, W. and Dochartaigh, B. (2009). What impact will climate change have on rural groundwater supplies in Africa? Hydrological Sciences Journal, 54, 690-703

Mann, B. (1945). Non-parametric tests against trend.Econometrika.13: 245-259.

McCarthy, T., Ellery, W. and Gieske, A. (1994). Possible ground water pollution by sewage effluent at camps in the Okavango delta: suggestions for its prevention. Botswana Notes and Records, 26, 129-138

Nkansah, M. and Ephraim, J. (2009). Physicochemical studies of water from selected boreholes in the Bosomtwi-AtwimaKwanwoma district of Ghana. The Pacific Journal of Science and Technology, 10, 643648

Sukhiha, B. (2008). Adaptation to climate change: strategies for sustaining groundwater resources during droughts. Geological Society, London, Special Publications, 288, 169-181 
Turkeş, M., Sümer, M. and Demir, I. (2002). World Health Organisation (WHO), (2003). Re-evaluation of trend and changes in Guidelines for drinking-water quality, mean,maximum, and minimum temperatures 23(11)1:45-196.

of Turkey for the period 1929-1999. World Health Organisation (WHO), (2004). International Journal of Climatology, 22, Guidelines for drinking-water quality, 3(11)1: 947-977. 45-196. 